\title{
Estimating the rockburst hazard of hard rocks based on laboratory test results
}

\author{
Iuliia Fedotova ${ }^{1 *}$, Nikolay Kuznetcov ${ }^{2}$ and Eduard Kasparyan $^{2}$ \\ ${ }^{1}$ MI FEB RAS, Laboratory of the digital methods research of natural and technical systems, 680000 \\ Turgeneva st., 51, Khabarovsk, Russia \\ ${ }^{2}$ MI KSC RAS, Laboratory of Geomechanics, 184209 Fersman st., 24, Apatity, Russia
}

\begin{abstract}
The results of laboratory tests of samples are used to estimate rock proneness to dynamic fractures, in particular, by brittleness index. A common drawback of the approaches in use is that they do not expressly consider the main condition of dynamic rock fracture - rock mass ability to accumulate energy when loaded. The article discusses the results of studies of the nature of elastic energy accumulation during loading and deformation of samples of various rocks under uniaxial compression in order to assess the degree of their explosion. The approach is original as it studies the deformation curve of rocks at the pre-peak stage that may be obtained with any standard equipment without the use of special-purpose test ("rigid") devices. Results of the studies conducted on standard test devices have allowed us to identify two different deformation patterns for the rock type tested with further establishment of criteria of rock classification by the degree of proneness to dynamic fractures. This approach is of practical value as it specifies the geomechanics zoning method of the rock mass and improves the assessment of rockburst hazard degree of specific areas at deposits being developed.
\end{abstract}

\section{Introduction}

The problem of dynamic fractures (rockbursts) of mine workings when developing mineral deposits is not a new one. The first official mention of these fractures dates back to 1738 when they were recorded at tinworks of England [1]. In the second half of the XIX century, rockbursts came to be observed during coal deposit development in Western Europe. Since then, the issue of rockbursts has attracted increasing attention [2-6].

The first rockbursts at Russian deposits were observed in 1944 at mines of Kizelovsky coalfield with strong tectonic disturbance of the rock mass and presence of rocks with high deformation and strength properties [1, 7-9]. Presently, increasing depth and scale of deposits development and mining intensification cause a growing number of dynamic rock fractures [10-12]. Earlier, rockbursts and mining-induced earthquakes were recorded in room work affected areas and areas of tectonic disturbances of the rock mass at underground mines. In the recent decade, they have even been recorded in open pit working areas and at the linking of underground mines and open pits.

*Corresponding author: fjulia@mail.ru 
Over the last 280 years, the problem of dynamic rock fractures has been studied in detail. A lot of actual data has been accumulated, various geomechanical monitoring systems of the rock mass state have been elaborated and implemented and various physical mechanisms of dynamic fractures have been proposed [13-16]. Effective organizational and technical measures have also been implemented to prevent rockbursts and decrease rockburst hazard when developing mineral deposits. This has been used as the basis for the elaboration of a host of normative documents that regulate mining techniques and patterns to reduce the risk of rockbursts. Special rockburst prediction and prevention services have been set up at mining enterprises to monitor the state of deposits being developed, which allows us to predict rockburst hazardous situations during mining to a certain degree.

All the deposits or their parts are classified as non-hazardous, prone and hazardous in terms of rockbursts. Prone rocks and rocks hazardous in terms of rockbursts include, in particular, rocks mass that contain rocks and ores with high elastic properties, prone to brittle fracture under load. Thus, determination of deformation and strength properties of ores and rocks is one of the main issues when estimating the degree of rockburst hazard during mining.

\section{Methodological frameworks}

By now the properties of rocks have been studied in detail. The methods for determining the parameters of mechanical properties have been developed, in particular, the strength characteristics under various loading modes. A wide range of laboratory test devices is available. Many of these devices are manufactured under industrial conditions.

By now, methods have been elaborated to determine rock deformation and strength properties under various loading conditions [17-20]. There is a wide choice of laboratory test devices to that end, many of them are produced on a commercial scale. Test results are used to estimate rock proneness to dynamic fractures, in particular, by brittleness index [21]:

$$
\mathrm{K}=\left[\sigma_{\mathrm{un}}\right] /\left[\sigma_{\mathrm{t}}\right],
$$

where $\left[\sigma_{\mathrm{un}}\right]$ is the rock compressive strength; $\left[\sigma_{\mathrm{t}}\right]$ is the rock tensile strength.

It is recognized that the higher is the brittleness index, the more rocks are prone to dynamic fractures.

More detailed information on the degree of rock proneness to dynamic fractures may be obtained from comparison of post-peak modulus on the post-peak part and elasticity modulus on the pre-peak part of the complete rock deformation curve (Fig. 1):

$$
\xi=\mathrm{M} / \mathrm{E} \text {, }
$$

where $\mathrm{E}$ is elasticity modulus; $\mathrm{M}$ is post-peak modulus.

Experiments have proved that with $\xi>1$, rocks are prone to manifestations of dynamic fractures [22], $\xi$ value is normally determined using unique special-purpose test devices so-called "rigid" compression apparatus that enable promotion of conditions of uniaxial and triaxial loading, but without elastic energy accumulated in the test devices during rock loading. A barrier to implementing this approach is the absence of commercially made "rigid" test devices.

A common drawback of the approaches considered is that they did not expressly consider the main condition of dynamic rock fracture - rock mass ability to accumulate energy when loaded.

Accordingly, the studies have been conducted to analyse the nature of elastic energy accumulation during loading and deformation of samples of various rocks under uniaxial compression to estimate the degree of their rockburst hazard. 


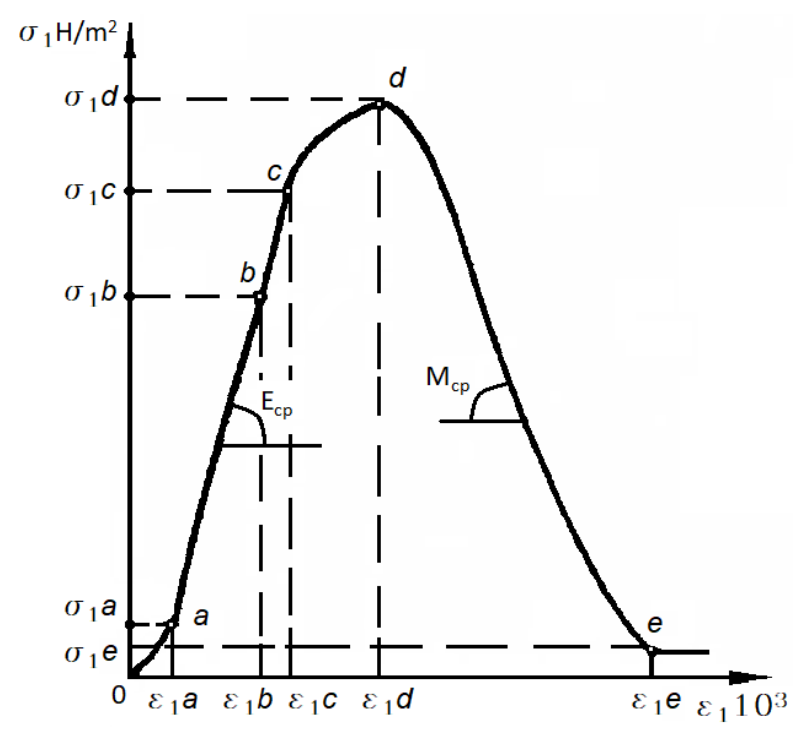

Fig. 1. Typical hard rock deformation chart (complete diagram) under uniaxial stress state.

Where: $\sigma_{1}-$ normal stress; $\varepsilon_{1}-$ linear (axial) deformation. Typical diagram sections: $0-a-$ area of changes in contact conditions of the rock volume tested; $a-b$ - area of completely elastic deformation, $\sigma_{1} a-$ maximum stress value, with which contact conditions of the rock volume tested stabilize, $\sigma_{1} b-$ perfect elasticity limit; $b-c$ - area of non-perfect elastic deformation, $\sigma_{1} c$ - elastic strength; $c-d-$ area of plastic deformation, $\sigma_{1} d$ - compressive strength; $d-e$ - area of post-peak deformation, $\sigma_{1} e-$ residual strength; $\mathrm{E}_{\mathrm{cp}}$ and $\mathrm{M}_{\mathrm{cp}}$ - average values of elasticity and post-peak moduli, correspondingly.

\section{Results and discussion}

Nine types of hard rocks from Murmansk region were tested to attain the set objective apatite-nepheline ores, ijolites and urtites of host rocks of Kukisvumchorrsky and Yuksporsky deposits (Khibiny rock massif), carbonatite-magnetite ores of Kovdorsky deposit (Kovdorsky rock massif), Kurkenpakhk iron-ore deposit (Zaimandrovsky iron-ore region).

In Khibiny rock massif, deposits are developed using open and underground techniques. At Kukisvumchorrsky and Yuksporsky deposits, mining conditions at depths of below $300 \mathrm{~m}$ from the day surface have been recognized as hazardous in terms of rockbursts and they are conducted with mandatory use of a set of organizational and technical measures against rockbursts. Kovdorsky and Kurkenpakhk deposits are open-worked. In terms of physical properties, some rocks of these deposits may also be prone to dynamic fractures starting at certain depths.

Tests were conducted using MTS 816 servohydraulic device (USA). Samples were cylinder-shaped with a height-to-diameter ratio of $2: 1$ and 4-5 samples of each rock were used.

During the study, the samples were loaded with up to $30 \%$ of the compressive strength and unloaded. Next, they were loaded until fractured and axial deformation values were recorded using strain gauges. Test results were used to plot "stress-deformation" dependences and to calculate strain energy values of each sample. The data obtained were averaged for each rock type.

Table 1 provides test results for various types of rocks and ores from the deposits studied and averaged values of their main physical parameters. 
Table 1. Main physical properties of the rocks studied

\begin{tabular}{|c|c|c|c|c|c|c|c|}
\hline \multirow[b]{2}{*}{ Rock type } & \multicolumn{2}{|c|}{ Strength } & \multirow{2}{*}{$\begin{array}{l}\text { Young's } \\
\text { Modulus } \\
\text { MPa·10 }\end{array}$} & \multirow{2}{*}{$\begin{array}{l}\text { Poisson } \\
\text { ratio }\end{array}$} & \multirow{2}{*}{$\begin{array}{l}\text { Density } \\
\mathrm{g} / \mathrm{cm}^{3}\end{array}$} & \multirow{2}{*}{$\begin{array}{c}\text { Critical } \\
\text { specific } \\
\text { strain } \\
\text { energy, } \\
W_{n}, \mathbf{M J} / \mathbf{m}^{3}\end{array}$} & \multirow{2}{*}{$\begin{array}{c}\text { Difference } \\
\text { between } \\
\text { WII and } \\
W_{p . e .} \%\end{array}$} \\
\hline & $\begin{array}{c}\text { Com- } \\
\text { pres- } \\
\text { sive } \\
\text { MPa }\end{array}$ & $\begin{array}{c}\text { Tensile } \\
\text { MPa }\end{array}$ & & & & & \\
\hline \multicolumn{8}{|c|}{ Khibiny massif rocks } \\
\hline $\begin{array}{l}\text { 1. Trachytoid } \\
\text { ijolite }\end{array}$ & 230 & 13 & 8.0 & 0.18 & 3.0 & 0.1856 & 8 \\
\hline $\begin{array}{c}2 . \\
\text { Unequigranular } \\
\text { urtite with } \\
\text { aegirine }\end{array}$ & 200 & 9 & 8.0 & 0.26 & 2.8 & 0.2376 & 1 \\
\hline $\begin{array}{l}\text { 3. Medium- } \\
\text { grained } \\
\text { massive urtite }\end{array}$ & 175 & 10 & 7.2 & 0.28 & 2.8 & 0.1758 & 0 \\
\hline $\begin{array}{l}\text { 4. Pegmatoid } \\
\text { urtite }\end{array}$ & 155 & 9 & 7.7 & 0.25 & 2.8 & 0.1324 & 3 \\
\hline $\begin{array}{l}\text { 5. Lenticular- } \\
\text { striped apatite- } \\
\text { nepheline ore }\end{array}$ & 145 & 7 & 6.6 & 0.20 & 2.9 & 0.1246 & 7 \\
\hline \multicolumn{8}{|c|}{ Rocks of Zaimandrovsky iron-ore region } \\
\hline 6. Gray gneiss & 140 & 11 & 6.9 & 0.20 & 2.8 & 0.1234 & 2 \\
\hline $\begin{array}{l}\text { 7. Gray } \\
\text { leucocratic } \\
\text { gneiss }\end{array}$ & 190 & 12 & 7.6 & 0.17 & 2.7 & 0.1107 & 10 \\
\hline \multicolumn{8}{|c|}{ Kovdorsky massif rocks } \\
\hline $\begin{array}{l}\text { 8. Calcite } \\
\text { carbonatite } \\
\text { with ijolite } \\
\text { inclusions }\end{array}$ & 80 & 5 & 5.0 & 0.22 & 2.5 & 0.0099 & 28 \\
\hline $\begin{array}{l}\text { 9. Apatite- } \\
\text { carbonate- } \\
\text { magnetite ore }\end{array}$ & 130 & 9 & 13.0 & 0.26 & 3.6 & 0.0433 & 2 \\
\hline
\end{tabular}

Let us review test results by the example of a sample of the weakest rock tested - calcite carbonatite (Fig. 2).

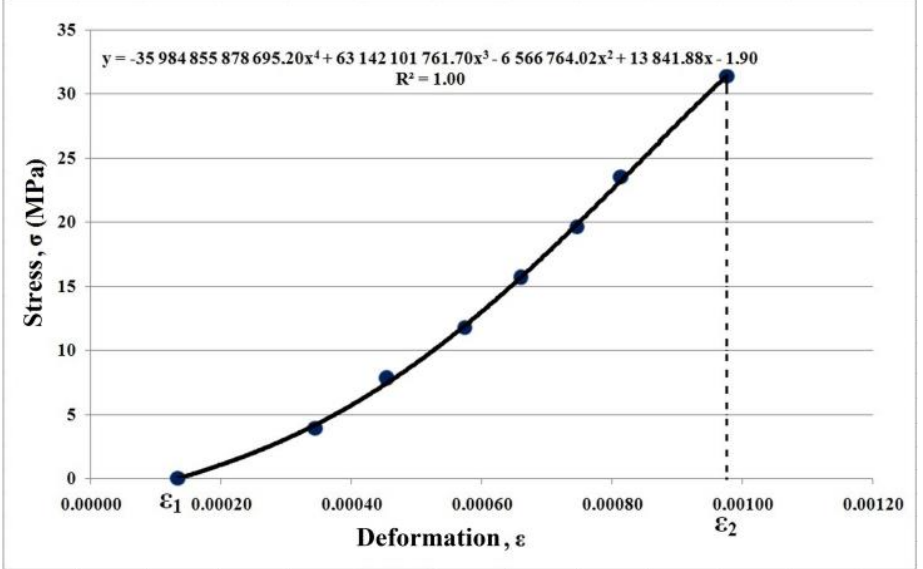

Fig. 2. Calcite carbonatite sample deformation chart 
As is seen from figure 2, the carbonatite sample deformation curve is concave and is approximated with a 4th order polynomial with high confidence. It should be noted that the deformation curve does not start with zero as irreversible deformations occurred in the sample during the cycle of loading-unloading to $30 \%$ from the compressive strength. Similar results were obtained for all other carbonatite samples studied.

The actual strain energy of sample to the strength limit was calculated as follows:

$$
W_{n}=\int_{\varepsilon_{1}}^{\varepsilon_{2}} \sigma(\varepsilon) d \varepsilon
$$

where $\sigma(\varepsilon)$ is the "stress-deformation" function (in this case, 4 th order polynomial), $\varepsilon_{1}$ and $\varepsilon_{2}$ are sample axial deformation values, accordingly, in the beginning and end of loading.

Calculations showed that $W_{n}$ energy for carbonatite samples was $0.0099 \mathrm{MJ} / \mathrm{m}^{3}$ on the average.

For comparison, let us consider the deformation chart of a sample of unequigranular urtite (Fig. 3) - one of the strongest rocks tested.

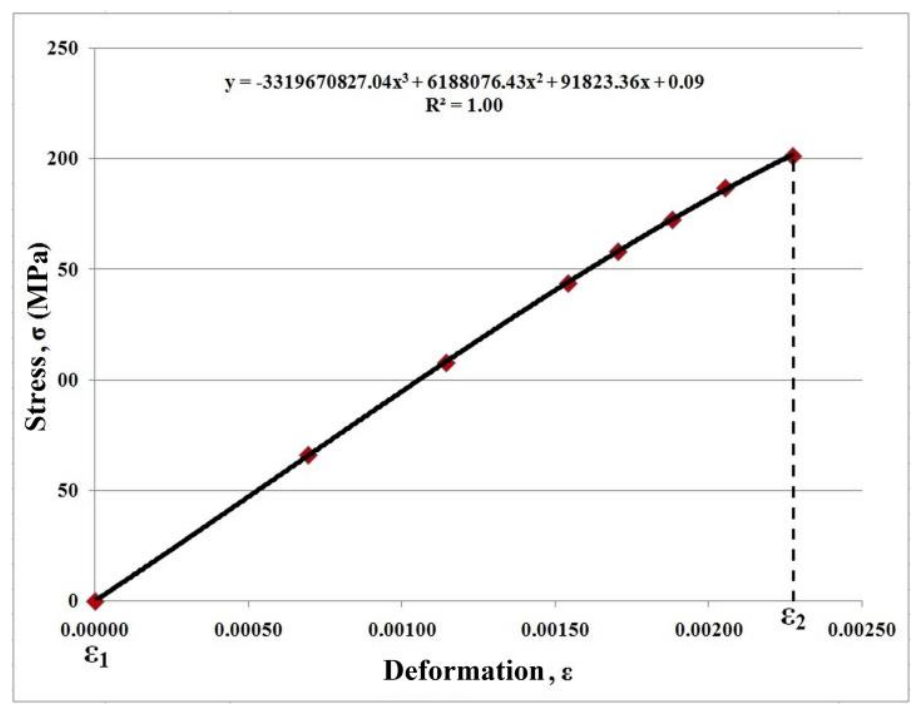

Fig. 3. Unequigranular urtite sample deformation chart

It follows from the data in figure 3 that the urtite sample deformation curve is a little convex, unlike carbonatite. Following loading-unloading to $30 \%$ from the compressive strength, deformation returned to zero, which is indicative of the almost perfect elastic behaviour of urtite deformation. The $W n$ energy value calculated for urtite samples was one-two orders higher $\left(0.2376 \mathrm{MJ} / \mathrm{m}^{3}\right)$ compared to carbonatites.

Analysis of data obtained revealed two different deformation patterns for tested rock types.

Figure 4 shows a typical deformation chart for carbonatites-like rocks (number 8 in the table). This chart is evidently concave and goes the below conventional line of perfectly elastic deformation OBC to the rock compressive strength. Similar results were obtained by [23] when testing samples of weak apatite-nepheline ores of Khibiny rock massif (compressive strength of $80 \mathrm{MPa}$ ) and phlogopite-diopside-olivinic ores of Kovdor rock massif (compressive strength of $40 \mathrm{MPa}$ ). 


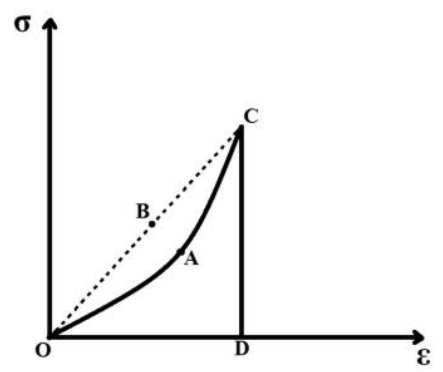

Fig. 4. Typical deformation chart of carbonatite-like rocks under uniaxial compression.

OBC - conventional line of perfectly elastic deformation. Point $\mathrm{C}$ - compressive strength; Point D axial deformation value matching to the compressive strength.

Actual strain energy of rocks to compressive strength is calculated as an integral value:

$$
W_{n}=\int_{O}^{D} \sigma(\varepsilon) d \varepsilon
$$

while estimated value of perfectly elastic strain energy - as an area of OBCD triangle:

$$
W_{p . e .}=\mathrm{S}_{\mathrm{OBCD}} \text {, }
$$

For carbonatites, $W_{n}$ will be lower than $W_{\text {p.e. }}$ strain energy in the assumption of perfect elasticity of the rock studied to compressive strength:

$$
W_{n}<\text { p.e. }
$$

In the experiments conducted, a difference between the actual and estimated elastic energy for carbonatites reached $30 \%$ and carbonatite samples disintegrated without fragment dispersion.

A different deformation pattern was observed when testing ijolites, gneisses, and most urtite samples. Here, deformation charts were also concave or approximated the best straight line. A difference between actual strain energy $W_{n}$ and conventional estimated energy $W_{\text {p.e. }}$ varied from 0 to $10 \%$. These rock samples disintegrated dynamically with fragment dispersion.

Deformation charts for a number of urtite samples were convex and actual strain energy $W_{n}$ exceeded conventional estimated energy $W_{p . e}$ by up to $5 \%$ (Fig. 5).

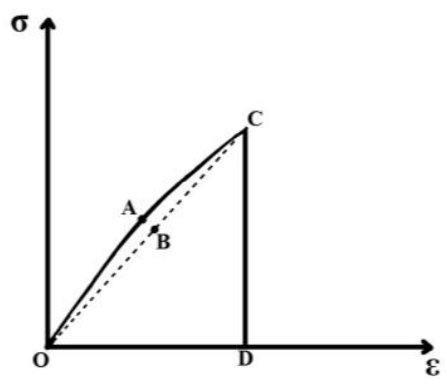

Fig. 5. Typical deformation charts of ijolites, urtites and apatite-nepheline ores under uniaxial compression.

OBC - conventional line of perfectly elastic deformation. Point C - compressive strength; Point D axial deformation value matching to the compressive strength. 
The samples disintegrated with an expressed dynamic pattern accompanied by intense energy release, strong noise, and fragment dispersion.

Results obtained allow us to establish criteria of rock classification by the degree of proneness to dynamic fractures.

In particular, if ratio (6) is kept and actual strain energy is lower than conventionally estimated perfectly elastic energy by more than $10 \%$, the rock may be classified as "nonhazardous in terms of rockbursts". Dynamic fractures of these rocks are unlikely to occur.

If this difference (subject to inherent sample composition variability) is less than $10 \%$ or actual strain energy exceeds conventional estimated perfectly elastic energy, rocks are prone to dynamic fractures and their rock mass must be classified as prone and hazardous in terms of rockbursts.

\section{Conclusions}

The laboratory test results obtained have allowed the following conclusions:

- if sample rock deformation chart matches the first pattern (accumulated strain energy is lower than estimated elastic one by more than $10 \%$ ), the rock is not prone to dynamic fractures. In this case, mine workings may only show static rock-pressure manifestations and will lose stability mainly in the form of individual inrushes limited by surfaces of various structure heterogeneities.

- if sample rock deformation chart matches the second pattern (samples are deformed and accumulated energy is lower than estimated elastic one by not more than $10 \%$ or exceeds it), the rock is prone to dynamic fractures and rockbursts may not be ruled out during mining.

Thus, the data obtained have revealed a possibility to use the results of standard tests to determine the degree of rockburst hazard of rocks. This approach enables more detailed elaboration of the geomechanical zoning method of the rock mass and a better differentiated estimate the degree of rockburst hazard of specific areas at deposits developed.

\section{References}

1. Avershin S.G. Rock bursts. Moscow: Ugletekhizdat, (1955)

2. Anderson E.M. The dynamic of faulting and dyke formation with application to Britain. Edinburg: London: Oliver and Boynd, (1951)

3. Hill F.G., Denkhaus H.G. Rock mechanics research South Africa, with special reference to rock burst and Strate movements in deep level gold mines. Transactions of 7-th Commonwealth Mining and Metallurgy Congress. London, 2 (1961)

4. Morisson R.K. Theory of Rockbursts. S. Afr. Min. and Eng. J. 63(3082). (1962)

5. Zubelewicz A., Mroz Z Treated as Problem of Dynamic Instability. R. Mech. and R. Eng. 16 (1983)

6. Xie H., Pariseau W.G. Fractal character and mechanism of rock bursts. Int. J. R. Mech. and Min. Sci. 30(4) (1993)

7. Petukhov I.M., Smirnov V.A. Rock bursts - a model of earthquakes. Forecasting and prevention of bursts. Experimental Seismology. Moscow, (1983).

8. Petukhov I.M., Ilyina A.M., Trubetskoy K.N. Forecasting and prevention of rockbursts in mines. Moscow: Publishing house of the Academy of Mining Sciences, (1977) 
9. Ushakov K.Z., Kaledina N.O., Kirin B.F., Srebnyy M.A., Dikolenko E.Ya., Ilyin A.M., Semenov A.P. Mining safety and rescue work. Moscow: Publishing house of the Moscow State Mining University (2002)

10. Kabwe E., Wang Y. Review on rockburst theory and types of rock support in rockburst prone mines. Op. J. of Saf. and Techn. 5 (2015)

11. Cai M. Prediction and prevention of rockburst in metal mines - A case study of Sanshandao gold mine J. of R. Mech. and Geotech. Eng., 8 (2016)

12. Ptacek J. Rockburst in Ostrava-Karvina coalfield. Procedia Engineering. 191 (2017)

13. Tarasov B.G. Fan-structure shear rupture mechanism as a source of shear rupture rockbursts. J. of the S. Afr. Inst. of Min. and Met. 114 (2014)

14. Kozyrev A., Fedotova Iu., Kasparyan E. Integrated complex geomechanical monitoring system of hard rock mines. Proceedings of 16th International Multidisciplinary Scientific Geoconference SGEM 2016. Book 1, vol1, Part A) (2016)

15. Xu N.W., Li T.B., Dai F., Zhang R., Tang C.A., Tang L.X. Microseismic monitoring of strainburst activities in deep tunnels at the Jinping II Hydropower station, China. R. Mech. and R. Eng. 49(3) (2016)

16. Jiang B., Wang L., Gu S., Zhang X., Li W. Study on rock bursts mechanism of TMB excavation for deep tunnel based on energy principle. J. of Min. and Saf. Eng. Vol. 34 (2017)

17. Ilnitskaya E.I., Teder R.I., Vatolin E.S., Kuntysh M.F. Rock properties and methods to determine them. Moscow: Nedra (1969)

18. Bieniawski Z.T. Estimating the strength of rock materials. Is. J. S. Afr. Inst. Min. Metall., 3 (1974)

19. Beron A.I., Vatolin E.S., Koifman M.I. Rock properties at various types and modes of loading. Moscow: Nedra, 1984.

20. Stavrogin A.N., Tarasov B.G. Experimental physics and mechanics of rocks. St.Petersburg: Nauka publishing house (2001)

21. Baron L.I. Rock hardness coefficient. Moscow: Nauka publishing house, (1972)

22. Petukhov I.M., Linkov A.M. Mechanics of rock bursts and outbursts. Moscow: Nedra (1983)

23. Turchaninov I.A., Iofis M.A., Kasparyan E.V. Basics of rock mechanics. Leningrad: Nedra (1989) 